\title{
Synthesis and Characterization of $\mathrm{Al}_{2} \mathrm{O}_{3} / \mathrm{ZrO}_{2}, \mathrm{Al}_{2} \mathrm{O}_{3} / \mathrm{TiO}_{2}$ and $\mathrm{Al}_{2} \mathrm{O}_{3} / \mathrm{ZrO}_{2} / \mathrm{TiO}_{2}$ Ceramic Composite Particles Prepared by Ultrasonic Spray Pyrolysis
}

\author{
In-Soo Shim and Chang-Seop Lee ${ }^{*}$ \\ Department of Chemistry. Keimvang Lniversity. Daegu 704-701, Norea \\ Receivedipril 7. 2001
}

\begin{abstract}
Fine ceramic particles of zirconia toughened alumina (ZTA). titania toughened alumina (TTA), and zirconiatitania toughened alumina (ZTTA) have been synthesized by ultrasonic spray pyrolysis (USP) at various temperatures from starting salt solutions of various compositions aiming for the development of catalytic material. These particles were characterized for properties such as shape, size and size distribution diffraction pattem. and chemical and phase composition of elements by scanning electron microscopy (SEM). particle size analyzer (PSA). x-ray diffraction (XRD). and inductively coupled plasma-atomic emission spectroscopy (ICPAES). Chemical compositions and sizes of ceranic composites have been controled by the stoichiometry of salt solutions and the flow rate of spraying solutions. The optimum experimental conditions for the various composite particle syntheses have been proposed.
\end{abstract}

Key words : Ultrasonic spray py rolysis (USP). Zirconia toughened alumina (ZTA). Titania toughened alumina (TTA). Zirconia-litania toughened alumina (ZTTA). Ccramic composite particle

\section{Introduction}

Ceramics have been widely used as a useful source of industrial and household materials. with the newly developed fine ceramics offering adranced capabilities. Since they are manufactured by well-controlled tecluiques using highly selected substances. fine ceramics are characterized by finely determined chemical compositions. well-designed structure. and superior properties. They also are superior to metal or organic polymer materials for various functions. Ceranic materials display chemical and thermal stability. electrical insulation. semiconductivity. piezoelectricity: corrosion resistance. and biocompatability. They also exhibit ligh dielectricity: chemical adsorption. sound absorption. antiradioactivity and optical transparency. and are easy to obtain since the main sources of fine ceramics such as alumina $\left(\mathrm{Al}_{2} \mathrm{O}_{3}\right)$, magnesia $(\mathrm{MgO})$, silica $\left(\mathrm{SiO}_{2}\right)$ are abundant in the earth. It is noteworthy that combining several different ceramic materials can create a material with new capabilities which produces ceramic composite material. This is particularly important since a thermally resistant material of ceranic composite material can substitute for the super metal alloys of $\mathrm{Ni}$. $\mathrm{Cr}$. and $\mathrm{Co}$. which are being used for the purpose of themal resistance and mechanical strength. Therefore. ceramic materials can now be used to minimize metal usage.'

Among the fine ceramics alumina has a variety of applications. it is used as sources for IC boards. IC packaging. and other industrial materials due to its electrical insulation and magnetic properties. Alumina's chemical composition also makes it useful as a catalyst or a catalytic support.

Zirconia is the third most widely used ceramic material after alumina and silica. It is a good source for structural material because of its phrsical and mechanical characteristics.
It displays piezoelectricity. semiconductivity, and ionic conductivity, making it useful for oscillators. thermistors. and oxygen sensors. Its high melting point and resistance to corrosion allows zirconia to be used as a source for fireproof materials or materials used in high temperature chemical processes.

Titania is used as sources for porcelain. polishing agent. medicine and cosmetics. and recently for optical catalysts and oxygen sensors that control the air/fuel ratio in automobiles. The synthesis of spherically-shaped powder is strongly required for the fabrication of these devices.

It has been of interest to combine the characteristic properties of these single ceramic material to a coniposite material. Ultrasonic spray pyrolysis that we employed in this study is a good technique to prepare spherically-shaped fine particles. In this technique. fine liquid droplets were formed from a starting salt solution using an ultrasonic oscillator. which then were changed to ultrafine particles through pyrolysis in a high temperature reaction furnace. This method produces fine spherically-shaped particles with an uniform size distribution. and especially in this case. each of the liquid droplets of the starting solution acts as a small reactor which can confine the inequality of particle composition on that spherical secondary particle. This method is also an easy and reproducible way to control the size distribution of particles as a function of concentration. Spray pyrolysis system can be divided into three main parts: sonicator which can generate fine liquid droplets. pyrolysis furnace of liquid droplets. and collector of the synthesized particles.

Kim et al. ${ }^{2}$ prepared $\mathrm{TiO}_{2}$ and $\mathrm{BaTiO}_{3}$ powder by ultrasonic spray pyrolysis from metal alkoxide solution in the temperature range of $400-900{ }^{\circ} \mathrm{C}$ with a resonance frequency of $1.6 \mathrm{MHz}$ and collected the powder with glass filters. The primary particles prepared by this method were 
about $0.02 \mu \mathrm{m}$ in si $/ \mathrm{c}$. Their si/es were independent of py roly sis temperature. but increased and then decreased with increasing concentration of salt solution.

V. Jokanov ic et $a l^{3}$ prepared high temperature ultrafine particles of $\alpha$-alumina from a starting solution of $\mathrm{AlCl}_{3}$ $6 \mathrm{H}_{2} \mathrm{O}$ and $\mathrm{Al}\left(\mathrm{NO}_{3}\right) \cdot 9 \mathrm{H}_{2} \mathrm{O}$. The droplet size was aboul 0.3 $\mu \mathrm{m}$ and particle size was smaller than that in the present study. The shape of the fine particles produced was almost the same as that of the liquid droplets. The fine particles of alumina synthesized undergo phase transition in the temperature range of $1073-1173 \mathrm{~K}$.

Chii-Shyang et $\mathrm{al} .^{+}$prepared ZTA powders containing more than $5.5 \mathrm{~mol} \%$ of $\mathrm{TiO}_{2}$ additive by hot-pressing for $\mathrm{I}$ hour at $1350^{\circ} \mathrm{C}$. They reported that the bending strength and hardness of ZTA improved as the amount of $\mathrm{TiO}_{2}$ increased.

Han et $a .^{5}$ produced alumina toughened zirconia (ATZ) by the alumina coating method and reported that they obtained ATZ with a relative density of higher than $99 \%$ by sintering the sample for 2 hours in the temperature range of $1450-15500^{\circ} \mathrm{C}$. They also showed that ATZ containing 20 $w 1 \%$ alumina represented $8 \mathrm{MPa} / \mathrm{m}^{1: 2}$ of breaking strenglh $\left(\mathrm{K}_{\mathrm{IC}}\right)$. which is higher than $6 \mathrm{MPa} / \mathrm{m}^{12}$ obtained by the ball mill method.

In this study. ultrasonic spray pyrolysis method was employed to prepare ccramic compositc particles of zirconia toughened alumina (ZTA), titania toughened alumina (TTA) and zirconia-titania toughened alumina (ZTTA) aiming for the development of catalytic material. The prepared fine particles have been characicrized by various icchniques and the effects of the concentration of solution. pyroly sis temperaturc. and reaction time on the propertics of ccramic compositc particles were investigated. The optimum experimental condition for the preparation of ceramic line particles werc also investigated.

\section{Experimental Section}

Preliminary Work for Single Materials. Fine particles of pure alumina and $\mathrm{ZrO}_{2}$ were synthesized and analyzed prior to our composite material of ZTA by ultrasonic spray pyrolysis. The results of characteristic analyses for alumina and $\mathrm{ZrO}_{2}$ were used as basis data for the work. We stinthesized alumina particles from $0.1 \mathrm{M}$ of $\mathrm{Al}\left(\mathrm{NO}_{3}\right)_{3} \cdot 9 \mathrm{H}_{2} \mathrm{O}$ in 7:3 water/ethanol mixed solvent at the drying zone temperatures of $400-550$ " $\mathrm{C}$. at pyrolysis temperatures of 850.900 .950 .1000 . and $1100^{\circ} \mathrm{C}$. which were dried at 100 "C for more than 2 hours and were analyzed. According to the XRD analysis. we observed the characteristic peaks corresponding to the $\gamma-\mathrm{Al}_{2} \mathrm{O}_{3}$ at all temperature ranges used in the experiment. which was more distinct at a ligher temperature. However, at temperatures higher than $1100^{\circ} \mathrm{C}$. new peaks showed up. which is assigned to the fomation of $\alpha-\mathrm{Al}_{2} \mathrm{O}_{3}$. consistent with the results reported by other group. ${ }^{6-19}$

For $\mathrm{ZrO}_{2}$. powders were produced through pyrolysis of $0.056 \mathrm{M}$ aquous solution of $\mathrm{ZrCl}_{2} \mathrm{O} \cdot 8 \mathrm{H}_{2} \mathrm{O}$ (Junsei. Japan. $\mathrm{CP})$ at 950 and $10500^{\circ} \mathrm{C}$. They were then collected and dried at $110^{\circ} \mathrm{C}$ for 2 hours and analyed with various techniques.

Preparation of Starting Solutions. Watcr soluble salts of zirconium. titanium. and aluminum wore used as cation supplies. The starting matcrials were the aquous solution of cach salt with a concentration of $0.05-\left(0,1 \mathrm{~mol} / \mathrm{l} . \mathrm{Al}\left(\mathrm{NO}_{3}\right)_{3}\right.$. $9 \mathrm{H}_{2} \mathrm{O}$ (Duksan. Korca. $\mathrm{FG}$ ) or $\mathrm{AlCl}_{3}$ (Duksan. Korca. FG) was used as a supply of aluminum cation. $\mathrm{ZrCl}_{2} \mathrm{O} \cdot 8 \mathrm{H}_{2} \mathrm{O}$ (Junsci. Japan. CP) for zirconium cation, and Ti[OCH( $\left.\left(\mathrm{CH}_{3}\right)_{2}\right]_{+}$ (Aldrich. USA. 99.999\%) for titanium cation. The starting solutions were prepared by dissolving precursors in distilled water in corresponding amount.

The $\mathrm{ZrO}_{2}$ contents of $\mathrm{ZTA}$ were varicd from $5 \%$ to $15 \%$ in every $5 \%$ and the $\mathrm{TiO}_{2}$ contents of TTA were varied to $2.5 \%$. $5 \%$ and $10 \%$. The $\mathrm{TiO}_{2}$ contents of ZTTA were saried in the range of $1.5-7.5 \mathrm{w} \%$ with the fixed amount of $15 \mathrm{w} 1 \% \mathrm{ZrO}$. so that the $\mathrm{Al}_{2} \mathrm{O}_{3}$ contents were resulted in the range of 77.5$83.5 \mathrm{w} \%$. According to the amount of $\mathrm{TiO}_{2}$ contained. they are denotcd as ZTTA-l (1.5 w\% $\%$. ZTTA-2 (3w1\%). ZTTA$3(4.5 w 1 \%)$. ZTTA-4 (6w $\%)$, and ZTTA-5 $(7.5 w \%)$ respectively.

Since $\mathrm{Ti}\left[\mathrm{OCH}\left(\mathrm{CH}_{3}\right)_{2}\right]_{4}$ can precipitate to $\mathrm{TiO}_{2}$ by reacting with water at room temperature. it is necessary to dissolve $\mathrm{Ti}\left[\mathrm{OCH}\left(\mathrm{CH}_{3}\right)_{2}\right]_{4}$ solution in $100 \mathrm{~mL}$ of absolute cthanol first and then adjust the concentration of salt solution with distilled water to avoid the precipitation problem.

Apparatus of Ultrasonic Spray Pyrolysis. Figure 1 shows the apparatus of ultrasonic spray py roly sis. It consists mainly of threc parts. which are sprayer. py roly sis furnace. and collector. The ultrasonic sprayer with resonant frequence of 1.6 $\mathrm{MH} \%$ cmployed was a modificd apparatus of general houschold ultrasonic humidificr (Dacwoo. KH-3550). Korca). which was connected to a reaction tube of the furnace. While the sprayed liquid droplets generated from ultrasonic sprayer were passing through reaction tube. they undergo heating. solvent craporation. pyrolysis. reaction with oxygen in the air. and finally form finc ceramic particles.

The reaction furnace was divided into two zones. one is a drying zone with a temperature range of $400-550^{\circ} \mathrm{C}$. and the

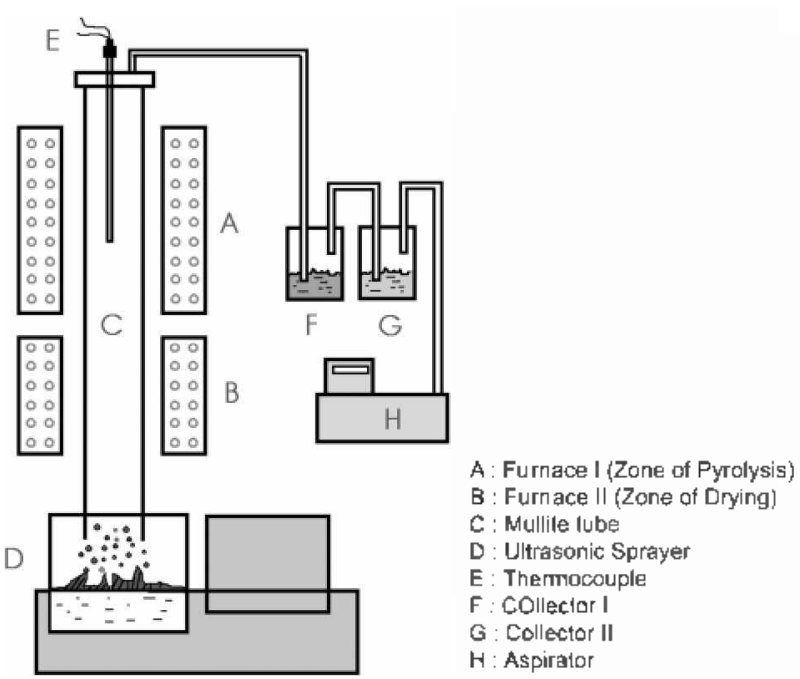

Figure 1. Schematic diagram of ultrasonic spray py rolysis system. 
other is a pyrolysis /one with a temperature range of 850 1400 ${ }^{\circ} \mathrm{C}$. B r running the experiment with the emperature gradient in these zones. it was possible to overcome the problem of producing irregular shaped particles which arised from a sudden heating and a rapid solvent craporation occurred in a single temperature systems. Thus spherical fine particles could be generated. The material of the reaction tube $(I D=5 \mathrm{~cm} . \mathrm{L}=150 \mathrm{~cm})$ was mulite and the temperature was measured by an external digital themometer in the drying tone. and by an internal themocouple in the pyrolysis fone. The temperature in the drying zone was adjusted to be $50 \%$ of that in the pyrolysis zone. that is. the temperature of powder synthesis

Fine particles were collected into a container containing distilled water by wet method. There were two collectors installed and most of the fine particles were collected by the first collector. The collected fine particles were dried ai 110 "C for 2 hours.

In the preparation of $5 \cdots 1 \%$ ZTA particles. ZTA was synthesized by raising the py roly sis temperature by $50^{\circ} \mathrm{C}$ in the range of $850-1100^{\circ} \mathrm{C}$. and also at $1200^{\circ} \mathrm{C}$. while for 10 $w 1 \%$ and $15 w 1 \%$ ZTA's. the particles were synthesized by raising the pyrolysis temperature by $50^{\circ} \mathrm{C}$ or $100^{\circ} \mathrm{C}$ in the range of $9\left(00-14000^{\circ} \mathrm{C}\right.$. The particles produced in this way were collected and dried at $110^{\circ} \mathrm{C}$. for 2 hours and then characterized.

In the case of TTA powder. $5 w 1 \%$ and 10 wi samples were able to be sprayed. while 15 wi\% sample was not. duc to its high viscosity. We thus synthesized 2.5 w $\%$ TTA in order to have the information about the general tendency, If $\mathrm{Ti}$ ion is included in aquous solution. it forms oxydized precipitates at room temperature. Therefore. the reaction solution needed to be cooled in order to keep the solution from the fomation of precipilates. In our spray experiment. we tried to avoid the formation of precipitates by spraying the solution within a small amount at a time. and cach time the solution was freshly made. The powder produced in this way was also dried at $110^{\circ} \mathrm{C}$ for 2 hours and then analyzed.

ZTTA powder was synthesized in a mamer similar to that of other cases.

Particle Analyses. The method of thermogravimetry (TG. SHIMADZU, DS-50. Japan) was used to determine the temperatures of pyrolysis and crystallization for the synthesized powder with the heating rate of $10^{\circ} \mathrm{C} / \mathrm{min}$ up to $1400^{\circ} \mathrm{C}$ in a $\mathrm{N}_{2}$ atmosphere. The phase analysis was performed by using $\mathrm{X}$-ray diffractometer (MAC. MOXHF. Japan) with a scanuing speed of $5.0 \mathrm{deg} / \mathrm{min}$ in the range of $10^{\circ}<2 \theta<90^{\circ}$. We also used the particle size analyzer (SHIMADZU, SA-CP3, Japan) to get the information of average size. surface area and size distribution for the particles. SEM (Jeol. JSM-5400. Japan) for the size and the shape. ICP-AES (JY50P. Jobin Yvon. France) for the ingredients of particles.

\section{Results and Discussion}

Characterization of ZTA Fine Particles. We sýnthesized zirconia toughened alumina (ZTA) through ultrasonic spray pyrolysis. We varied the content of $\mathrm{ZrO}_{2}$ to be 5,10 , and 15 wt \%. It was reported ${ }^{1]}$ that in the synthesis of ZTA using cmulsion spray hydrolys sis. the mass ratio of $\mathrm{Al}_{2} \mathrm{O}_{3} / \mathrm{ZrO}_{2}$ was adjusted to be $80 / 20$. because in this condition the amount of square-shaped $\mathrm{ZrO}_{2}$ becomes a maximum at room temperalure and also with this ratio. ZTA cxhibits maximum lracturc strength.

The ZTA particles containing 5 w $\%$ of $\mathrm{ZrO}_{2}$, which was prepared through pyroly sis of $0.16 \mathrm{M} \mathrm{AlCl} / \mathrm{ZrCl}_{2} \mathrm{O} \cdot 8 \mathrm{H}_{2} \mathrm{O}$. shows distinct XRD peaks of $\gamma$-alumina but does not show the characteristic peaks which show the cxistence of $\mathrm{ZrO}_{2}$ clcarly at low temperature $\left(850^{\circ} \mathrm{C}\right.$ ). Howcicr. above $950^{\circ} \mathrm{C}$. the characteristic peaks of $\mathrm{ZrO}_{2}$ become sharp. which means that in the preparation of ZTA particles. the reaction temperature needs to be set above $950^{\circ} \mathrm{C}$. and this is the same lor the casc of 10 w $\mathrm{t} \%$ of $\mathrm{ZrO}$, too.

For ZTA particles containing $15 \mathrm{wt} \%$ of $\mathrm{ZrO}_{2}$. the characteristic peaks of both alumina and zirconia appeared in the temperature range of $90\left(0-14000^{\circ} \mathrm{C}\right.$. It was found from the XRD results of 5.10 .15 w $1 \%$ ZTA that as the amount of zirconia increases. the temperature of showing ZTA peaks became higher.

In Figure 2, the X-ray diffraction patterns of ZTA powders containing 5. 10. and $15 \mathrm{wt} \%$ of $\mathrm{ZrO}$. which were prepared from $\mathrm{AlCl}_{3} / \mathrm{ZrCl}_{2} \mathrm{O} \cdot 8 \mathrm{H}_{2} \mathrm{O}$ with pyrolysis tempreature of $12000^{\circ} \mathrm{C}$. are shown. The characteristic peaks of $\alpha-\mathrm{Al}_{2} \mathrm{O}_{3}$ in $\mathrm{X}$-ray dillraction patten start to appear above $1200^{\circ} \mathrm{C}$. which is the temperature of phase transition of $\gamma$ form to $\alpha$ form. Therelore. in ultrasonic spray pyrolysis. it would bc possible to synthesize $\alpha-\mathrm{Al}_{2} \mathrm{O}_{3}$ powders above $1200^{\circ} \mathrm{C}$ withoul any further process.

Figure 3 is the SEM photographs of ZTA containing 5. 10. and $15 w 1 \%$ of $\mathrm{ZrO}$. which show that the particles synthesized above $1300^{\circ} \mathrm{C}$ are finc. as small as $1-2 \mu \mathrm{m}$ in sizc. spherically-shaped. and do not show coalescing phenomena which were shown at lower temperature.

In Table I. the particle sice distributions of the above samples synthesized at $1200^{\circ} \mathrm{C}$ through py rolysis are listed. The mean diameter of the particle was deternined to be

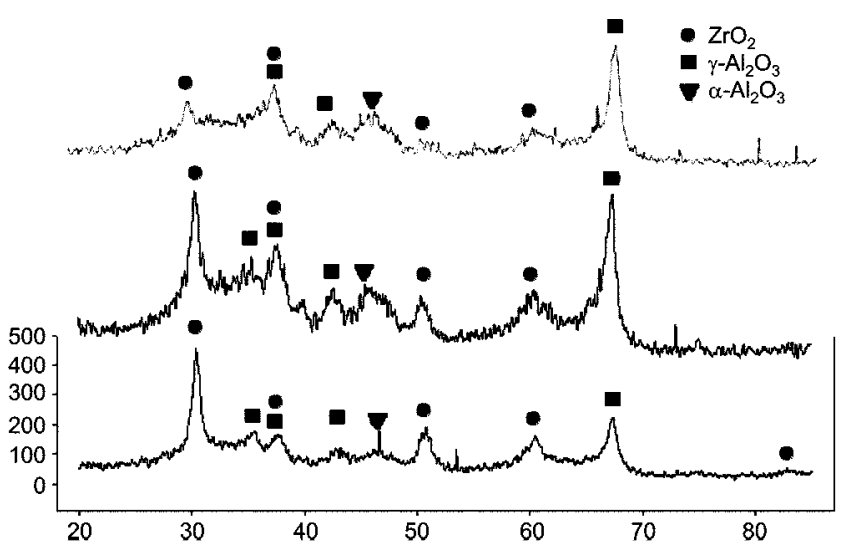

Figure 2. X-ray dilliraction patterns of as-prepared ZTA powder by ultrasonic spray pyrolysis at $550^{\circ} \mathrm{C}$ drying zone and $1200^{\circ} \mathrm{C}$ pyrolysis zome with $\mathrm{AICl} / 7 . \mathrm{rCl}_{2} \mathrm{O} \cdot 8 \mathrm{H}_{2} \mathrm{O}$ aqueous solution (bottom: 15

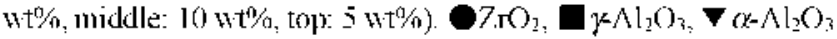




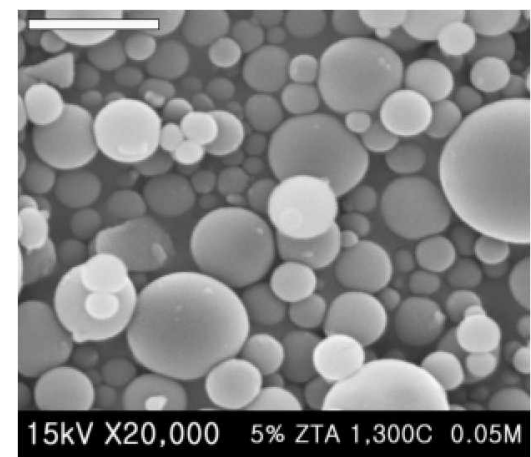

$5 w 1 \% 1300{ }^{\circ} \mathrm{C}$
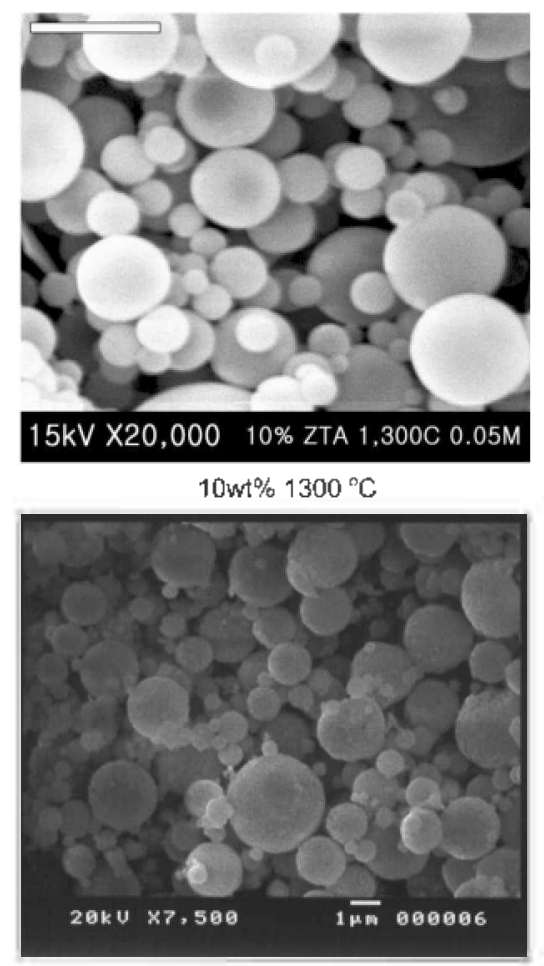

$15 w t \% 1300^{\circ} \mathrm{C}$

Figure 3. SLM photographs of as-prapared $2 \mathrm{IA}$ powider by ultrasonic spray prrolysis at 550 " $\mathrm{C}$ ' drying zone and various tempetature of prolysis 7one with $\mathrm{Al}\left(\mathrm{NO}_{3}\right)_{3} \cdot 9 \mathrm{H}_{2} \mathrm{O} / 7 \mathrm{CCl}_{2} \mathrm{O} \cdot 8 \mathrm{H}_{2} \mathrm{O}$ aqueous solution

Table 1. Particle size distributions of as-prepared $\angle 1 A$ powder by ultrasonic spray prolysis

\begin{tabular}{ccccc}
\hline Sample & $\begin{array}{c}\text { Median } \\
\text { Diam. } \\
(\mu \mathrm{m})\end{array}$ & $\begin{array}{c}\text { Surlace } \\
\text { Arca } \\
\left(\mathrm{m}^{2} / \mathrm{g}\right)\end{array}$ & $\begin{array}{c}\text { Mołal } \\
\text { Diam. } \\
(\mu \mathrm{m})\end{array}$ & $\begin{array}{c}\text { Stanclard } \\
\text { Deviation } \\
(\mu \mathrm{m})\end{array}$ \\
\hline $5 \% \angle \mathrm{lA}$ & 1.47 & 1.913 & 1.58 & 0.078 \\
$10 \% \angle \mathrm{lA}$ & 1.32 & 2.043 & 1.28 & 0.111 \\
$15 \% \angle \mathrm{lA}$ & 1.03 & 1.979 & 1.11 & 0.183 \\
\hline
\end{tabular}

about $1.3 \mu \mathrm{m}$. regardless of the amount of $\mathrm{ZrO} 2$ contained. but the modal diameter decreases and particle size distributions are narrowed as the anount of $\mathrm{ZrO}_{2}$ increases. It is estimated that the lattice size of $\mathrm{ZrO}_{2}$ is less than that of $\mathrm{Al}_{2} \mathrm{O}_{3}$.

Table 2 lists the result of elemental analysis by ICP-AES
Table 2. ICP-AFS data of as-prepared 7TA powder by ultrasonic spray pyrolysis

\begin{tabular}{|c|c|c|c|c|}
\hline \multirow{2}{*}{ Sample } & \multirow{2}{*}{ Elements } & $5 \%$ & $10 \%$ & $15 \%$ \\
\hline & & Con (ppm) & $\operatorname{Con}(p p m)$ & Con (ppm) \\
\hline $9500^{\circ} \mathrm{C}$ & $\mathrm{Al} / \mathrm{ZI}$ & $63.2 / 10.7$ & $407 / 87.8$ & - \\
\hline $10000^{\circ} \mathrm{C}$ & $\mathrm{Al} / \angle \mathrm{I}$ & $98.7 / 12.3$ & $232 / 87.9$ & $295 / 130$ \\
\hline 1050 ' C & $\mathrm{Al} / / \mathrm{r}$ & $79.4 / 12.1$ & $277 / 81.7$ & $250 / 132$ \\
\hline 1100 ' $\mathrm{C}$ & $\mathrm{Al} / \angle \mathrm{I}$ & $98.9 / 11.5$ & $148 / 88.4$ & $179 / 134$ \\
\hline 1150 ' C' & $\mathrm{Al} / \angle \mathrm{I}$ & - & $401 / 85.9$ & $281 / 133$ \\
\hline 1200 ' C' & $\mathrm{Al} / \mathrm{Zr}$ & $92.7 / 11.4$ & $109 / 87.5$ & $300 / 128$ \\
\hline
\end{tabular}

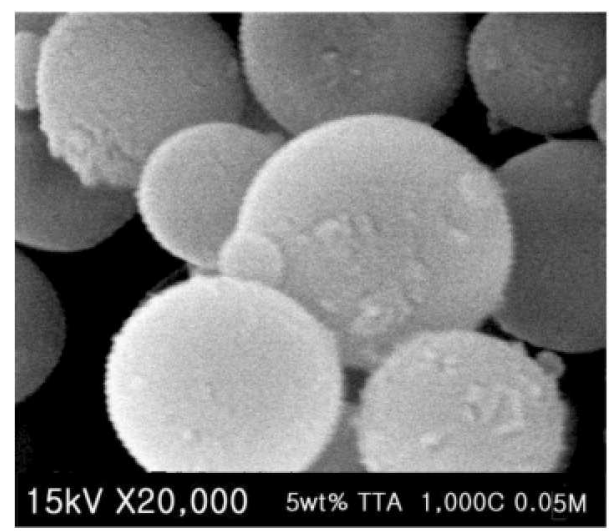

(a)

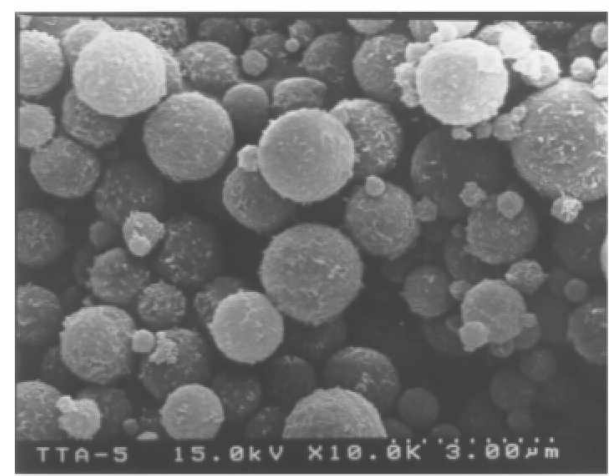

(b)

Figure 4. SEM pholographs of as-praparal T"IA powder by ultrasonic spray pyrolysis at 500 " $\mathrm{C}$ of drying zonce and $10000^{\circ} \mathrm{C}$ temperature of pyrolysis zome with $\mathrm{Al}\left(\mathrm{NO}_{3}\right)_{3} \cdot 9 \mathrm{H}_{2} \mathrm{O} / \mathrm{Ti}\left[\mathrm{OCH}\left(\mathrm{CH}_{3}\right)_{2}\right]_{\text {. }}$ aqueous solution. a) 5 wt\% TTA powder $(\times 20,000)$ b) $(\times 10,000)$.

method for ZTA particles. As are shown. the compositions of each wt" $\%$ of ZTA particles were a little different from what we calculated and estinlated in the preparation of starting solution. For example, for the ZTA particles which we prepared to be $5 \mathrm{wt} / \%$ of zirconia, we obtained about 15 wt $\%$ of $\mathrm{Zr}$ at temperature of lower than $1000^{\circ} \mathrm{C}$. and about $10 \mathrm{wt} \%$ of $\mathrm{Zr}$ at temperature of higher than $1000^{\circ} \mathrm{C}$.

For 10 and $15 \mathrm{nt} \%$ samples, this deviation beconies large. However. in tems of the amount of $\mathrm{Zr}$ simply. there is a certain rate of increment of $\mathrm{Zr}$ content from 5 to $10.15 \mathrm{wt} \%$. Another thing is. the powders synthesized at temperatures of higher than $1000^{\circ} \mathrm{C}$ show a stable amount of $\mathrm{ZrO}_{-}$contained.

Analysis of TTA Fine Particles. Even though there is an example of preparation of $\mathrm{TiO}_{2}$ powders through ultrasonic 
spray py roly sis using aquous solution of $\mathrm{TiCl}_{\downarrow}$ as a source. there was no exidence of TTA synthesis through this technique. In this experiment similar to the case of ZTA we prepared titania toughened alumina containing 5,10 , and 15 $w 1 \%$ of titania. Unfortunately. since the samples of TTA containing more than $10 \mathrm{w} 1 \%$ of Ti cation had difficultics to be sprayed due to the increase of viscosity. we excluded 15 $w 1 \%$ TTA powders from a characteristic analysis.

Figure 4 shows the SEM photographs of 5 w\% of TTA which was synthesized through pyrolysis using mixed solution of $0.05 \mathrm{M}$ and $0.075 \mathrm{M}$ of $\mathrm{Al}\left(\mathrm{NO}_{3}\right)_{3} \cdot 9 \mathrm{H}_{2} \mathrm{O} /$ $\mathrm{Ti}\left[\mathrm{OCH}\left(\mathrm{CH}_{3}\right)_{2}\right]_{4}$. The prepared fine particles are represented to be spherical in shape as are shown in the photographs even though there are some traces of broken particles or particles with emply cores. The size of the particles were measured to be aboul $2 \mu \mathrm{m}$ while their size distribution was not uniform

According to the result of size analy sis of $2.5 .5 .10 \mathrm{wt} \%$ of TTA particles shown in Figure 5. which were synthesized through $1000{ }^{\circ} \mathrm{C}$ pyrolysis using $0.05 \mathrm{M}$ of $\mathrm{Al}\left(\mathrm{NO}_{3}\right)_{3}$. 9 $\mathrm{H}_{2} \mathrm{O} / \mathrm{Ti}\left[\mathrm{OCH}\left(\mathrm{CH}_{3}\right)_{2}\right]_{4}$. the particles show a relatively narrow distribution with a median diameter of $0.7-1.2 \mu \mathrm{m}$. The result of elemental analy sis of particles using ICP-AES technique reveals different compositions from what wc estimated. as was the case in ZTA. The evaluated amount of Ti contained in TTA particles synthesized at $850^{\circ} \mathrm{C}$ was 5.42 wi\%. which was close to what we estimated. but that in TTA particles synthesized at $1000{ }^{\circ} \mathrm{C}$ was lar from what wo expected. The deviation of this experimental result in high temperature was not properly understood.

In Figure 6. the X-ray diffraction patterns of TTA powders containing $2.5 \mathrm{wl} \%$. $5 \mathrm{wl} \%$. and $10 \mathrm{wl} \%$ of $\mathrm{TiO}_{2}$. which were prepared from $\mathrm{AlCl}_{3} / \mathrm{Ti}\left[\mathrm{OCH}\left(\mathrm{CH}_{3}\right)_{2}\right]_{7}$ with pyrolysis tempreature of $1000{ }^{\circ} \mathrm{C}$. are shown. As shown in the ligure. the characteristic peaks of $\mathrm{TiO}_{2}$ in $\mathrm{X}$-ray diffraction paticrn appcars as a small scalc in the $5 \mathrm{w} \%$ of $\mathrm{TiO}_{2}$ and it grows more and more as the contents of $\mathrm{TiO}_{2}$ increase. which shows the corresponding ratio of $\mathrm{TiO}_{2}$ in TTA powders.

Analysis of ZTTA Fine Particles. Since we had experienced
Sy'nthesizing fine particles containing additives such as ZTA and TTA using ultrasonic spray pyrolysis. it is tricd to add zirconia and titania together into alumina. So lar. the tochnique used to synthesize these 3 kinds of composite powders. ZTA. TTA, and ZTTA. was mostly a direct mixing of separately produced powders by hot pressed method. thus the method that we use is very convenient way for the preparation of spherical fine particles of these ccramic composites.

In this study, we fixed the content of zirconia to be 15 wt $\%$, and increased the content of titania by small amount from $1.5 \mathrm{w} \%$ to $7.5 \mathrm{w} \%$ in order to prepare the mixed solution of $0.05 \mathrm{M}, 0.075 \mathrm{M}$, and $0.1 \mathrm{M}$ ol $\mathrm{Al}\left(\mathrm{NO}_{3}\right)_{3} \cdot 9 \mathrm{H}_{2} \mathrm{O} /$ TilOCH$\left.\left(\mathrm{CH}_{3}\right)_{2}\right]_{4}$ and synthesized ZTTA particles through pyrolysis at $1000{ }^{\circ} \mathrm{C}$. For the ZTTA particles produced through $10000^{\circ} \mathrm{C}$ pyrolysis from $0.05 \mathrm{M}$ mixed solution. It was able to observe the characteristic dilfraction patterns for $\gamma$-alumina and zirconia. but not for titania. as is shown in Figure 7. This may duc to the lact that the peak position of titania is near those of alumina and zirconia. and also the

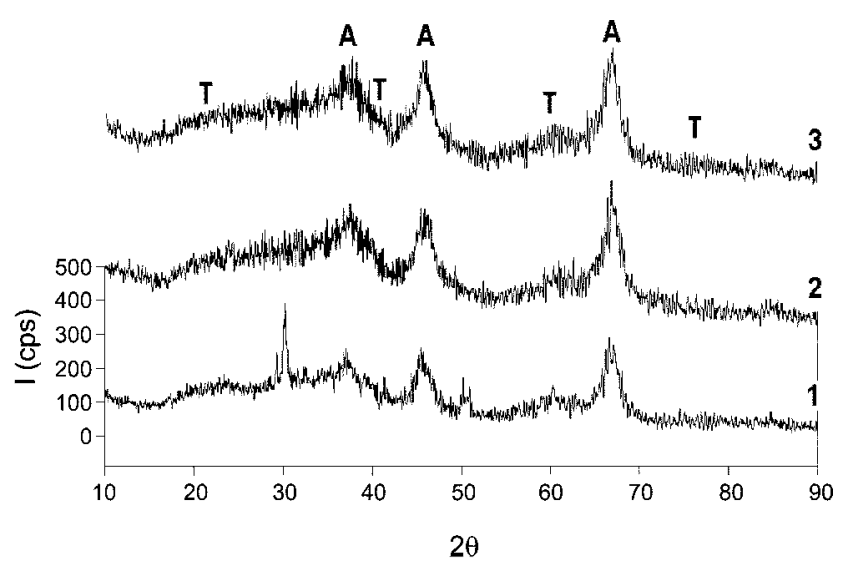

Figure 6. X-ray diffraction patterns of as-prepared TTA powder by ultrasonic spray pyrolysis at $500{ }^{\circ} \mathrm{C}$ drying $70 n e$ and $1,000{ }^{\circ} \mathrm{C}$ pyrolysis zone with $0.05 \mathrm{M}$ mixed aplwous solution. $\mathrm{A}$ and $\mathrm{I}$ indicales the characteristic peaks of $\gamma \mathrm{Al}_{2} \mathrm{O}_{3}$ and $\mathrm{TiO}_{2}$ respectively: ( $1: 2.5$ w $\%$ TTA. $2: 5$ w $\%$ TTA, $3: 10$ : $\%$ TTA)
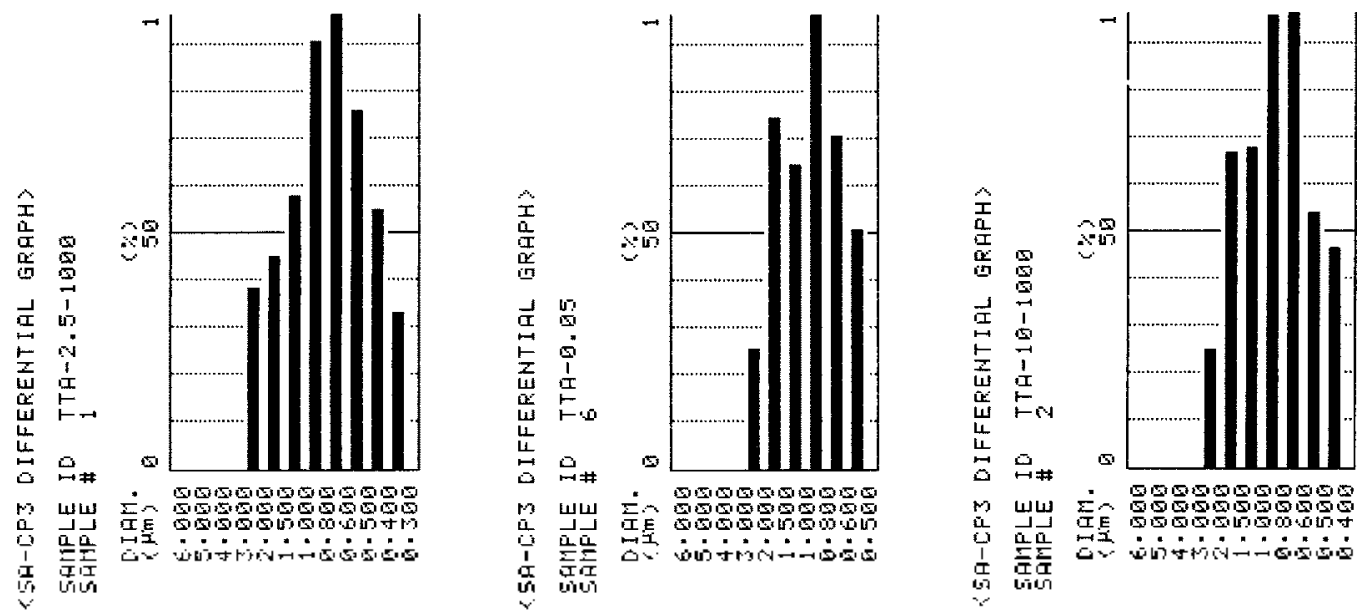

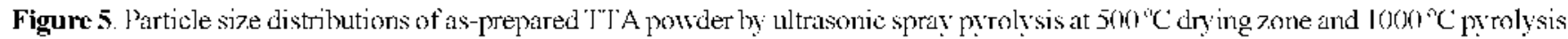
7one with $\left.0.1 \mathrm{M} \mathrm{Al}(\mathrm{NO})_{3}\right)_{3} \cdot 9 \mathrm{H}_{2} \mathrm{O}$ ) aqueous solution. (I: 2.5 w.t\%, $2: 5 \mathrm{wt} \%, 3: 10 \mathrm{wt} \%$ ) 


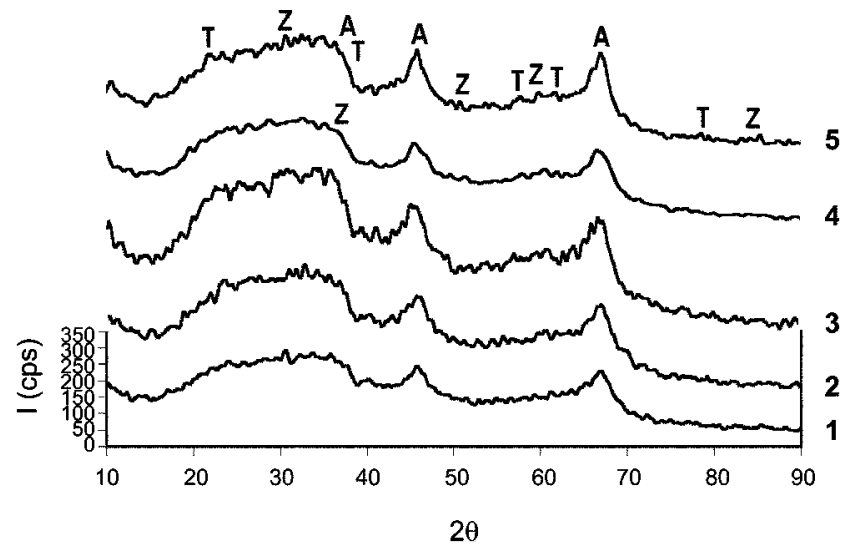

Figure 7. X-rat difliaction patlents of as-prepared Zl"lA pouder by ullasonic spray pyroly sis at $500^{\circ} \mathrm{C}$ drying zone and $1,0000^{\circ} \mathrm{C}$ prolysis zone with $0.05 \mathrm{M}$ mixed aqueous solution. $\wedge, 7$ and $T$ indicate the characteristic peaks of $\gamma-\mathrm{Al}_{2} \mathrm{O}_{3}, 7 \mathrm{rO}_{2}$ and $\mathrm{TiO}_{2}$ respectively: (1: Zl"IA-1, 2: ZI"lA-2, 3: ZI"lA-3, 4: Zl"IA-4, 5: ('I'IA-5),

amount of titania is relatively low.

The results of ICP-AES elemental analy sis listed in Table 4 tcll us that the amount of alumina was lower than what we estimated. on the other hand. the amount of zirconia (which we fixed the quantity) was more than we added. The amount of titania was also a little bit more than we added. Adjusting the amount of titania to be $3 w 1 \%$ secmed to be a reasonable condition for the preparation of ZTTA to have desired compositions.

The deviation of the real amount of each component from what we calculated in the first place. which happened commonly in most cases. is the problem necessary to be improved in this ultrasonic spray py rolysis.

In Figure 8. the SEM photographs of ZTTA synthesized through $1000^{\circ} \mathrm{C}$ pyrolysis from $0.075 \mathrm{M}$ mixcd solution are shown. Similarly to what is observed in ZTA cases. most of the ZTTA particles containing 1.5 to $6 \mathrm{wt} \%$ of titania are spherical in shape. and are fine in size even if they do not have a uniform distribution. However, the ZTTA particles synthesized at 1000 showed a significant coalescing of particles and a production of particles with emply cores. The reason for this is that there may be a rapid pyrolysis in the surface and also inside the solution at the same time due to the heat cvolved from mixing alcohol with water. and can be improved by adjusting the synthetic temperature and the condition of py rolysis such as a residence time. etc.

Table 5 provides the data for size distribution of ZTTA sy nthesized at $1000^{\circ} \mathrm{C}$ pyroly sis using $0.05 \mathrm{M}$ mixed solution. The size of ZTTA particles becomes larger as the amount of $\mathrm{TiO}_{2}$ increases and as that of $\mathrm{Al}_{2} \mathrm{O}_{3}$ decreases. and the surface area of particles follows the same tendency. This is an opposite trend to that of ZTA. where the particle size became smaller with the amount of zirconia increasing. The sire distribution is wide as was shown in SEM photographs.

\section{Conclusions}

The line particles of zirconia toughened alumina (ZTA). titania toughenod alumina (TTA) and zirconia-titania toughened alumina (ZTTA) were synthesized through ultrasonic spray pyrolysis at various concentrations and temperatures. The prepared particles were collocted by wet process and analy/ed to investigate the following characteristic propertics by XRD. PSA. SEM. and ICP-AES techniques after being dricd.

The particle sizes and size distributions of produced ZTA and ZTTA particles were able to be controlled as a function of experimental condition such as the reaction temperature. solvent. concentration of solution. the power of oscillator. clc.

ZTA particles were difficult to be synthesized at lower temperaturc. while above the temperature of $1000^{\circ} \mathrm{C}$. good crystalline particles were produced. As the temperature went up. spherically-shaped fine particles with a narrow sise distribution were generated. The amount of $\mathrm{ZrOS}$ in ZTA particles were examined to be higher than $5-15 \mathrm{wt} \%$ of estimated values. The median diameter of the particles was found to be about $1.376 \mu \mathrm{m}$ and the average surface arca was measured to be $1.978 \mathrm{~m}^{2} / \mathrm{g}$.

For TTA particles, even if there were some broken parts or empty parts observed. most of the particles were showil as

Table 3. Particle size distributions of as-prepared TTA powders by ultrasonic spray pyrolysis

\begin{tabular}{|c|c|c|c|c|c|}
\hline Sammple & $\begin{array}{l}\text { Median Diam. } \\
(\mu \mathrm{m})\end{array}$ & $\begin{array}{l}\text { Surlace Area } \\
\qquad\left(\mathrm{m}^{2} / \mathrm{g}\right)\end{array}$ & $\begin{array}{l}\text { Modal Diam. } \\
\text { ( } \mu \mathrm{m})\end{array}$ & $\begin{array}{c}\text { Concentration } \\
(\mu \mathrm{m})\end{array}$ & $\begin{array}{l}\text { Standaral Deviation } \\
\qquad(\mu \mathrm{m})\end{array}$ \\
\hline $2.5 \backsim 1 \% \mathrm{I} l \mathrm{AA}$ & 0.82 & 2.175 & 0.72 & 1.0 & 0.086 \\
\hline $5 w 1 \% \mathrm{TlA}$ & 0.96 & 2.040 & 1.22 & 0.05 & 0.121 \\
\hline $10 \leqslant 1 \% \mathrm{I} l \mathrm{~A}$ & 0.89 & 2.110 & 0.74 & 0.05 & 0.167 \\
\hline
\end{tabular}

Table 4. ICP-AFS datá of as-prepared 7TTA powder by ultrasonic spray pyolysis

(unit: $\mathrm{nt} \%)$

\begin{tabular}{|c|c|c|c|c|c|c|c|c|c|c|c|c|}
\hline \multirow{2}{*}{ Samples } & \multicolumn{3}{|c|}{ Calculatod Valu } & \multicolumn{3}{|c|}{$0.05 \mathrm{M}$} & \multicolumn{3}{|c|}{$0.675 \mathrm{M}$} & \multicolumn{3}{|c|}{$0.1 \mathrm{M}$} \\
\hline & $\mathrm{Al}$ & $\mathrm{Zr}$ & $\mathrm{Ti}$ & $\mathrm{Al}$ & $\mathrm{Zr}$ & Ii & $\mathrm{Al}$ & $\mathrm{Zr}$ & $\mathrm{Ti}$ & $\mathrm{Al}$ & $\angle \mathrm{r}$ & Ti \\
\hline 7.TTА-1 & 8.3 .5 & 15 & 1.5 & 77.13 & 20.81 & 2.06 & 76.09 & 22.23 & 1.71 & 72.33 & 25.16 & 2.31 \\
\hline 7.TTА-2 & 82 & 15 & $\hat{3}$ & 73.98 & 22.88 & 3.12 & 71.06 & 24.99 & 405 & 75.13 & 21.63 & 3.24 \\
\hline 7.TTA- 3 & 80.5 & 15 & 4.5 & 71.88 & 2.3 .06 & 5.06 & 71.89 & 22.68 & 5.43 & 71.08 & 23.57 & 5.35 \\
\hline 7.TTA-4 & 79 & 15 & 6 & & & & آ72.52 & 21.08 & 6.41 & & & \\
\hline
\end{tabular}




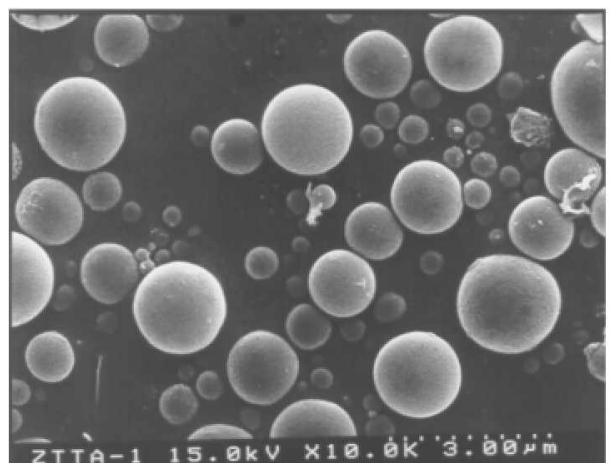

(a)

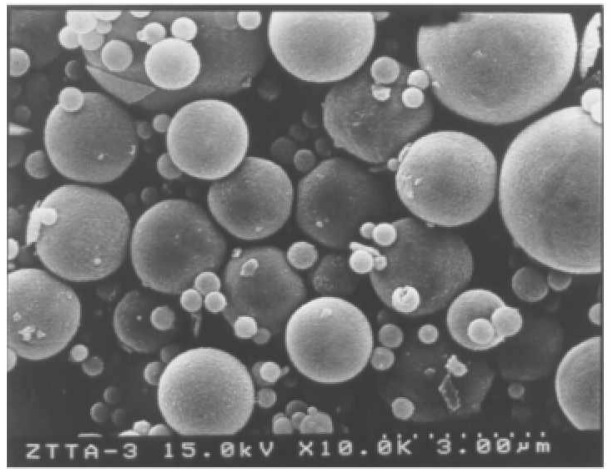

(c)

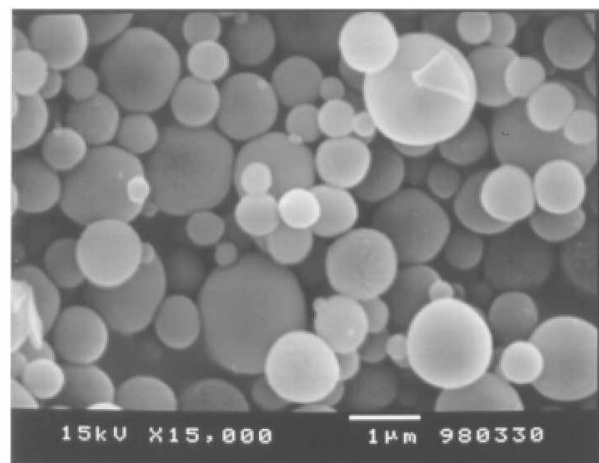

(b)

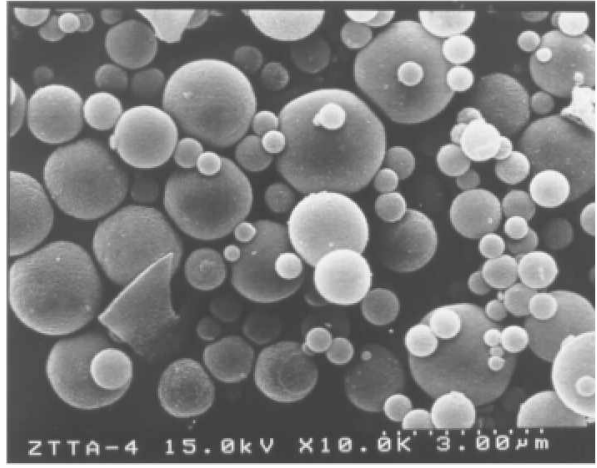

(d)

Figure 8. SFM photographs of as-prapared 7TTA powder by ultrasonic spray pyrolysis at $500^{\circ} \mathrm{C}$ drying zone and $10000^{\circ} \mathrm{C}$ temperature of proly sis zone with $0.075 \mathrm{M} \wedge \mathrm{l}\left(\mathrm{NO}_{3}\right)_{5} \cdot 9 \mathrm{H}_{2} \mathrm{O} / 7 . \mathrm{rCl}_{2} \mathrm{O} \cdot 8 \mathrm{H}_{2} \mathrm{O} / \mathrm{Ti}\left[\mathrm{OCH}(\mathrm{CH})_{2}\right.$. l aqueous solution. a) $\left.\left.\left.7 \mathrm{TT} \wedge-1, \mathrm{~b}\right) 7 \mathrm{TT} \wedge-2, \mathrm{c}\right) 7 \mathrm{TT} \wedge-3, \mathrm{~d}\right)$ Zl'IA-4.

Table 5. Particle size distributions of as-prepared $0.05 \mathrm{M}$ 7.TTA powder by the ultrasonic spray prolysis

\begin{tabular}{|c|c|c|c|c|}
\hline Sample & $\begin{array}{l}\text { Median } \\
\text { Liam. } \\
(\mu \mathrm{m})\end{array}$ & $\begin{array}{c}\text { Surlace } \\
\text { Arca } \\
\left(\mathrm{m}^{2} / \mathrm{g}\right)\end{array}$ & $\begin{array}{l}\text { Modal } \\
\text { Diam. } \\
(\mu \mathrm{m})\end{array}$ & $\begin{array}{l}\text { Standard } \\
\text { deviation } \\
(\mu \mathrm{m})\end{array}$ \\
\hline Zl"lA-1 & 1.08 & 3.755 & 1.25 & 0.836 \\
\hline$\angle \mathrm{I} l \mathrm{lA}-2$ & 0.93 & 3.818 & 0.92 & 0.357 \\
\hline$\angle \mathrm{I} 1 \mathrm{AA}-3$ & 0.70 & 3.518 & 0.74 & 0.167 \\
\hline$\angle \mathrm{I} 1 \mathrm{AA}-4$ & 0.77 & 3.193 & 0.78 & 0.168 \\
\hline$\angle \mathrm{I} l \mathrm{lA}-5$ & 0.70 & 2.884 & 0.74 & 0.090 \\
\hline
\end{tabular}

spherical in shape. In the preparation of TTA particles containing higher than $10 \mathrm{wt} \%$ of titania. improved condition of synthetic process is required because the viscosity of solutions containing higher than $10 \mathrm{wt} \%$ of titania is so high to be easily sprayed. The particles produced were fine and spherically -shaped with the average size smaller than $2 \mu \mathrm{m}$.

ZTTA particles synthesized were fune and sphericallyshaped. and the median diameter of smaller than $1 \mu m$ and surface area of $3.434 \mathrm{~m} \% / \mathrm{g}$ were determined. The analyzed contents of alumina in ZTTA's were found to be lower than the estimated values. that of zirconia was a little higher than the estimated value. while that of titania was close to the estimated value.

Acknowledgment. This study has been supported in part by grant from CAPT of Keimyung University designated by
KOSEF and in part by grant from Namsun Aluminum Co. LTD.

\section{References}

1. The editorial statti Industrial Investigation Association. Techology of tine Coramics: Ki-jeon Research Cooperation: Seoul. Korea. 1992: 14.

2. Kim. 1). I.: Kim. II. J . Sorean (erant Soc. 1989, 26(5). (9)1.

3. Johanovic. V.: Janactovic. Di.: Spasicé. A. M.: Ustokovicé D. Material Tr(msactions, JM1. 1996. 37(4).627.

4. Chii. S.: Chang. Y.-J. J. Mater Re's. 1996. $11(6) .1683$.

5. I lan. K. R.: Park, S. J.: I Iong. K. S.: Iurn. II. W. J. Ko'man Soc. ind Sci. 1993 6(2). 225.

6. Chminelli. R. R. M.S. Thesis The Pennsylyania State University: 1983.

7. Sato. T.: Ozawa. F.: Ihama. S. J. Appl (7km. Biotechol. 1978. 281.811 .

8. Tsuchida, T: Sakata. A: Furuichi. R.: Ishii. T. Thesnocthnica ACT:1981, t30.91.

9. Drobot, N. M.; Fone, K. G.: Buvanowa, N. F. Kinetics and Catclusis 1970. $11(6) .1280$.

10. Lee. J. H.: Cho. H. J.: Park. S. I. J. Konem Cerm. Soc. 1991. $28(10) .831$.

11. Kim, C. H.; I.ee, 1) II.: I ee C. S. I.ee, I3. G. J. Korean C'eram Soc. $1997,3+1(10), 1006$

12. Yoot1, K. II: Nam, D. I. J. Watert Sci. 1995, 30, 3415

13. Janachović. Dj: Jokanovic. V.: Kostić-Grozdcnovic nn. Lj: Zivković. Lj.: Ushokovic. D. J Materials Res. 1996. M(7). 1706.

14. Roy. D. M.: Neurgaonkar. R. R.: Hollcran. T. P. O.: Roy. R. Am. Cerant Soc. Bull 1977, $56(11)$ I 123

15. Kantraki, S.: I Iran, K.: (Otsuka, N.: Sailo, 7. Vogwo-Kyokai Shi 
1983. $91(2) .81$

16. Ruthner. M. J. Industrial Production of Aulticomponent ('eranic Powders by theans of the Spray Roasting fechmique: Vincelvini. P.. Iid.: ] Iset ier Scientific Publishing Co.: Annsterdam. Netherlands. 1988: p 515.

17. Lin. T. Q.: Sakurai. O.: Mizutani. N.: Kato. M. J. Mat. Sci. 1986. 21. 3698 .

18. 1shizawa 11: Sakusai, O.: Mizutani. N.: Kato, M. K. IogroKiokar Shi 1985. 93(7), 382
19. Nogami. K.: Sakurai. O.: Mizutani. N.: Kato. M. Yogner-Kiokai Shi 1987. 95(7). 682 .

20). Ishizawa, H.: Sahurai. (O): Mizutani, N.: Kato, M. im. Cram Soc. Bull. 1986. 65(10), 1399)

21. Sakurai. O.: Mizutani. N.: Kato. M. Yogne-Kiohai Shi 1986. $9+(8) .813$.

22. Seo. K. L.: Lee. C. S. I. Konw (7hm. Scc. 2000. $+4(6) .592$,

23. I ee C. S.: Chang. II. S. Korean l'otont $2002-0340398$.

24. I.ee C. S.: Chang- II. S. Korean Patont 2002-0340429) 